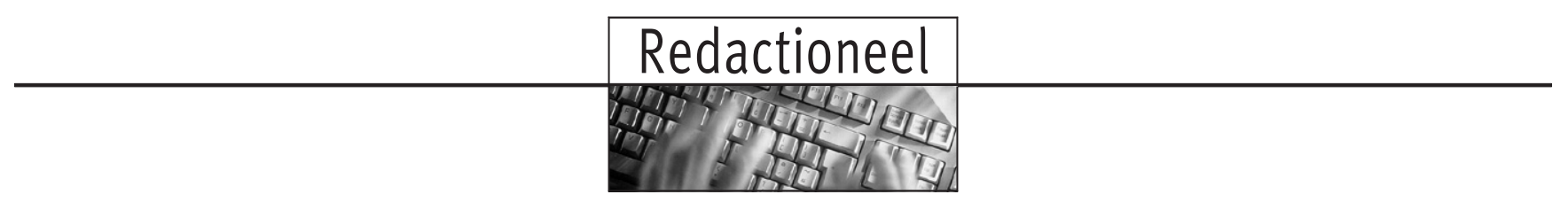

\title{
Voorbereiden op de toekomst
}

Wereldwijd overdenken we de gevolgen van de financiële crisis - inclusief of landen nog wel aan hun betalingsverplichtingen kunnen voldoen - en wat de gedwongen veranderingen betekenen voor onze oude gewoonten van overconsumptie, snel veel geld verdienen en hoog verbruik van grondstoffen en energie, die allen sterk waren gericht op korte termijn doelen.

De uitdaging ligt de komende decennia in de opbouw van een duurzame samenleving, waarbij we leren onze bronnen te gebruiken binnen de cycli van de natuur. ${ }^{1} \mathrm{We}$ moeten leren te passen in de ecosystemen waar we deel van zijn, we kunnen deze niet verder plunderen. We hebben de kans opnieuw een gemeenschap op te bouwen met gedeelde idealen en waarden waarin de kloof tussen de haves en have-nots wordt verkleind. Deze kans moeten we wel grijpen. De overheid verkeert in een cruciale positie. ${ }^{2}$ Enerzijds heeft de overheid het bancaire systeem gered, jammer genoeg zonder al te veel randvoorwaarden te stellen, anderzijds moet de overheid mede daardoor de aankomende periode draconische bezuinigingen doorvoeren, ook en juist in de gezondheidssector. Ondertussen moet de staat gezag heroveren, ook en juist in $\mathrm{Ne}$ derland.

Wat betekenen deze ontwikkelingen voor de positie van onze public health? Beleidsmatig scoort de sector goed. Preventie wordt breed omarmd, niet alleen in onze eigen sector. Ook in de curatieve zorg en de GGZ bestaat grote bereidheid mensen gezond te houden in plaats van pas te reageren bij ziekte. In het onderzoek lopen de zaken goed. Universitaire afdelingen floreren en werken goed samen met het werkveld in succesvolle academische werkplaatsen. De opleidingssituatie waarin maar kleine aantallen artsen zich specialiseren tot een functie in de public health is niet ideaal, maar ook niet problematisch. De praktijk van de public health doet zijn werk op degelijke wijze. Zie de succesvolle uitvoering van pandemische griepvaccinatie voor 0-4 jarigen en het wakker schudden van de landelijke politiek rond Q koorts.

Toch wil het public health denken en werken maar niet domineren. Terwijl daar juist grote behoefte aan is, juist ook in de curatieve acute en chronische zorg. ${ }^{3}$ Het individuele karakter van die zorg vraagt om aanvulling vanuit de collectieve zaak. Meer dan ooit tevoren kunnen we kennis delen, een gezamenlijke taal ontwikkelen, kunnen we het unieke individuele met het collectieve universele verbinden. Maken we daar in ons eigen vak optimaal gebruik van? Er is nog een wereld te winnen:

- De public health sector kan veel innovatiever: er is bijvoorbeeld een belangrijke rol voor ons is weggelegd in het verbinden van de medische en sociale sectoren op wijkniveau. Een paar voorbeelden. Zitten we al aan tafel met projectontwikkelaars en woningcorporaties om te praten over het leefklimaat of de zorg in een nieuwe of opnieuw in te richten wijk? Waar blijven de digitale poliklinieken SOA bestrijding? Weten we al hoe we de effecten van de gewenste geïntegreerde eerste lijn (waarin de public health participeert) in de wijk kunnen meten?

- De public health instellingen zijn veelal sterk gericht op instituutsbehoud, hun (politieke) bestuurders en managers op behoud van pluche en erg afhankelijk van overheidssubsidie: dat maakt ze (nu al) te bestuurlijk defensief en te weinig inhoudelijk vernieuwend, terwijl in dit laatste onze kracht behoort te liggen.

- Opvallend is dat de public health sector weinig is gericht op samenwerking: samenwerking met eerste lijn en ziekenhuis vindt maar mondjesmaat plaats en met welzijn hangt dit af van persoonlijke initiatieven, terwijl dit structureel geregeld zou moeten zijn. Wat lukt in Canada en Zweden moet hier ook kunnen.

Alhoewel politici in aanloop naar de gemeenteraadsverkiezingen ten onrechte zwijgen over bezuinigingen, komen die er wel aan. Hebben we dan op tijd een goed verhaal klaar? De denktanks in de public health zijn verdacht stil, terwijl de politiek een antwoord wil geven op de vraag: wat voor gemeenschap willen we? Public health waar bent $\mathrm{u}$ ?

Juist dit voorjaar komen veel rapporten (onder andere VTV 2010, Staat van de Zorg 2010, RVZ advies Nieuwe ordeningen in de zorg, RGO advies Kind en ziekte: onderzoek voor gezondheid) beschikbaar, dus informatie te over. De moderne media stellen ons verder in staat verbondenheid te creëren. Door het loslaten van oude werkvormen komt creatieve geest vrij om locale netwerken voor gezondheidszorg, maar ook voor onderwijs of energie op te zetten. We kunnen nu met elkaar een niveau van functioneren bereiken, dat vroeger was voorbehouden aan een kleine elite. De kritische massa is er al. Daarmee kunnen we nieuwe ontwikkelingen mogelijk maken.

De opdracht voor de public health is vooral leiderschap te ontwikkelen. Leiderschap om de broodnodige vernieuwing voor elkaar te krijgen waarin een nieuwe visie op public health (de vorige dateert al weer van 2000), een web-based strategie, proefprojecten en een slimme lobby centraal zullen staan. Dit leiderschap zal minder mannelijk en meer vrouwelijk worden, dat wil zeggen leiderschap zal niet meer op pikorde, maar op samenwerking zijn gericht en meer partnerschap betekenen. 
Het NCVGZ congres 2010 met als titel Preventie en zorg: beter in balanś wil een lans breken voor deze vernieuwing door speciale aandacht voor de verbreding van allerlei samenwerkingsverbanden, bij voorkeur op wijkniveau, voor innovatieve ict-mogelijkheden en voor wat deze tijd van ieder van ons aan leiderschap vraagt. Ik wens u veel inspiratie!

\section{Koos van der Velden}

\section{LITERATUUR}

1. Doorn M van. Het wiel opnieuw uitvinden. Cycli en niveaus van leiderschap. Haarlem: Double Healix Educational Media, 2010.

2. Tromp J. Val aan, overheid, val aan! Interview met Nobelprijswinnaar Joseph Stiglitz. De Volkskrant 6 februari 2010, p 35.

3. Advies Stuurgroep Zwangerschap en Geboorte. Een goed begin. Veilige zorg rond zwangerschap en geboorte. Utrecht: Advies Stuurgroep Zwangerschap en Geboorte, 2009, 